\title{
Review:
}

\section{Background of recent developments of passenger railways in China, the UK and other European countries}

\author{
Roderick A. SMITH, Jing ZHOU \\ (Department of Mechanical Engineering, Imperial College London, London SW7 2AZ, UK) \\ E-mail: roderick.smith@imperial.ac.uk; zhoujing_zju@126.com \\ Received Sept. 25, 2014; Revision accepted Nov. 3, 2014; Crosschecked Nov. 12, 2014
}

\begin{abstract}
This paper, based on a lecture given during tour undertaken in May 2014 of key railway establishments in China, consists of a brief introduction to the history and comparisons of railways in the UK and China, a description of rail speed-up in the last few decades in the UK, and notes of current high speed trains. Similar brief details are given of high speed in Europe. Brief mention is made of comparative railway safety. The development of high speed rail in China is discussed and the UK High Speed development plan is briefly introduced. The paper concluded that high speed train system has tremendous advantages in increasing the efficiency and convenience of transport without adding to carbon generation.
\end{abstract}

Key words: Railways, High speed, Safety, History, Vehicles, Infrastructure, System doi: $10.1631 /$ jzus.A1400295

Document code: A

CLC number: U271; U238

\section{Early railway development in China and the UK}

The first rail line in China was built in 1876, during the last days of the Qing Empire, to connect foreigners' settlements in Shanghai with the river docks at Wusong. The trading company Jardine, Matheson facilitated the import of British equipment, but the line was short lived and was removed less than a year later by an irate local governor. After this false start, rail development was slow. By the start of the 20th Century, China had just 370 miles of track, compared with 21000 miles for Great Britain and more than 182000 miles in America. However, every modern Chinese government has seen railroads both as a symbol of China's economic independence and as a powerful force for national cohesion; and the railway has grown both physically and in national importance during the post-World War 2 era. Approximately $30000 \mathrm{~km}$ in 1945 has grown to more

\footnotetext{
Corresponding author

(b) ORCID: Roderick A. SMITH, http://orcid.org/0000-0001-52028003; Jing ZHOU, http://orcid.org/0000-0003-3791-1871

(C) Zhejiang University and Springer-Verlag Berlin Heidelberg 2014
}

than $100000 \mathrm{~km}$ today, nearly half of which is electrified. China now has $6 \%$ of the world's railways and carries $20 \%$ of the world's rail traffic.

The first major passenger railway in Britain was that between the northern cities of Liverpool and Manchester. George STEPHENSON and his locomotive Rocket played a major in initiating this first true intercity passenger railway. Essentially Rocket was a prototype for all the steam engines to come and is now preserved in the Science Museum in South Kensington. Robert, the son of George, was the engineer of the first long intercity line connecting the capital London and the second city Birmingham. In 1847 George became the first President of the Institution of Mechanical Engineers and was followed by Robert his son as the second President. The first author of this paper was proud to be the 126th President in 2011-2012. Mention could be made of many names associated with the heroic era of engineering during the rapid growth of the railways in the UK: perhaps Isambard Kingdom Brunel deserves special mention, not only for his achievements in railways, but also for the design of huge steamships which connected his Great Western Railway with America. 


\section{Further development of the railways}

The railways in the UK grew rapidly in extent in the 19th century and reached a peak in the early 20th. The railways had been built and operated by many different private companies with the result that there was duplication, unnecessary competition and incoherence in the system. The two World Wars and the depression of the Thirties left the railways in poor physical shape when they were nationalised and were run by the state from 1948. The network was sharply contacted in the late 1950s and 1960s in order to make it more viable economically in the face of competition from private car ownership which increased strongly in these decades. In 1994 the railways were privatised once again: with very mixed results. Vertical integration was lost as the railway was fragmented into many parts in a most probably misguided attempt to inject competition. Costs have risen dramatically, but passengers have increased in number and are now back to the 1910 peak (Fig. 1).

It is instructive to compare some basis statistics of the railways in China and the UK: Germany and Japan have been added to the comparison. Table 1 shows the basic data: as is well known, China is a very large country and has a huge population. The result is that although it has the largest network in route length in the world, it only amounts to the length of a cigarette, $70 \mathrm{~mm}$, per person. Japan has more than twice this figure and the UK more than three times. The greatest difference is in the average length of railway journey: an astonishing $518 \mathrm{~km}$ in China (a huge justification for the new high speed network) compared with only $17 \mathrm{~km}$ in Japan, a figure arising from the dense commuter journeys in Tokyo and Osaka in particular. The UK and Germany have more balanced figures of around $40 \mathrm{~km}$. In the case of the UK, the area round London accounts for a high proportion of railways business: very little traffic is generated in Scotland, Wales, the west of England, and north of a line connecting Manchester and Leeds. This geography of population has, of course, implications for future high speed developments. In contrast, the population of China is more concentrated on the east side of the country and there are many cities with large populations; 160 greater than 1 million including 15 cities in conurbations greater than 5 million. Again these are fertile conditions for high speed rail.

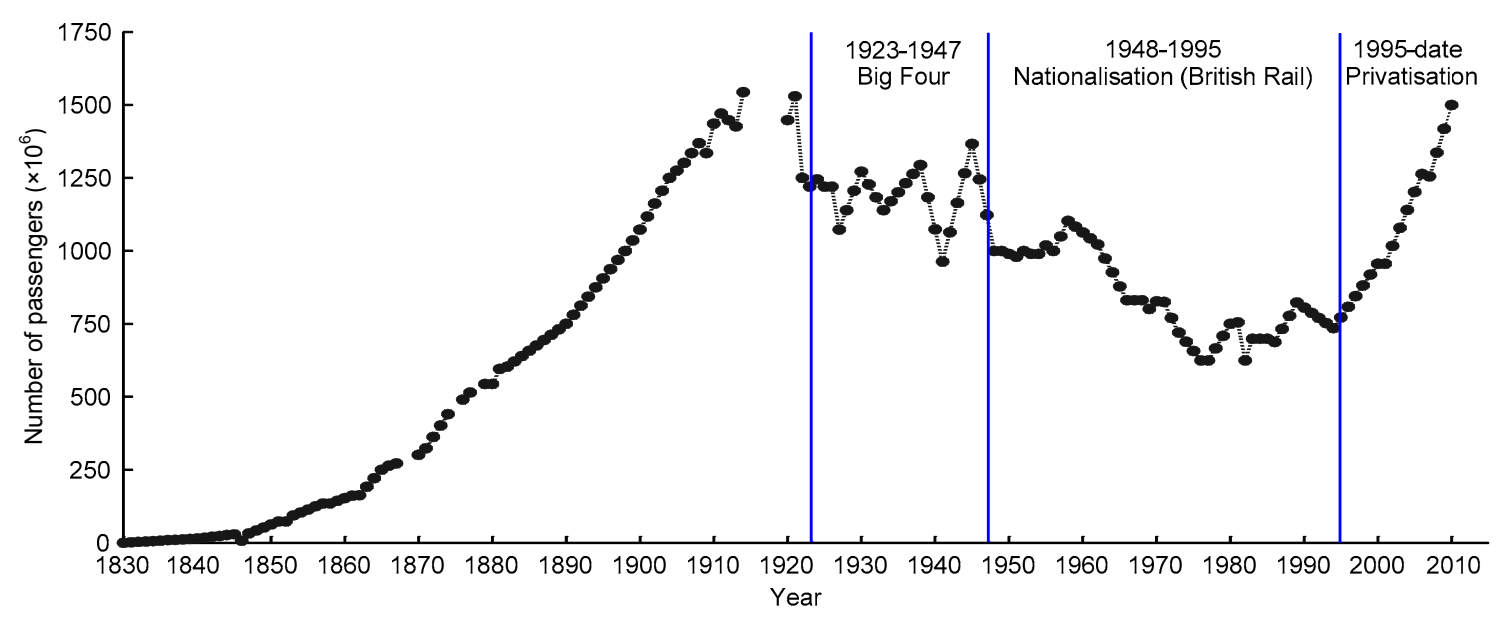

Fig. 1 Historical development of rail passenger volume in the UK

Table 1 Some international railway comparisons

\begin{tabular}{lcccccc}
\hline Country & $\begin{array}{c}\text { Area } \\
\left(\times 10^{6} \mathrm{~km}^{2}\right)\end{array}$ & $\begin{array}{c}\text { Population } \\
\left(\times 10^{6}\right)\end{array}$ & $\begin{array}{c}\text { Route } \\
(\mathrm{km})\end{array}$ & $\begin{array}{c}\text { Route/person } \\
(\mathrm{km} / \text { million })\end{array}$ & $\begin{array}{c}\text { Average } \\
\text { journey }(\mathrm{km})\end{array}$ & Intensity $^{*}$ \\
\hline China & 9.640 & 1351 & $1 \times 10^{5}$ & 70 & 518 & 26.9 \\
UK & 0.242 & 62.8 & 15775 & 25 & 40 & 9.3 \\
Germany & 0.349 & 82 & 33707 & 41 & 41 & 6.3 \\
Japan & 0.378 & 127.5 & 20852 & 16 & 17 & 51.6 \\
\hline
\end{tabular}

* Intensity is 1000 passenger $\mathrm{km} /($ route $\mathrm{km} \cdot \mathrm{d}$ ) 


\section{Speed-up and high speed rail in the UK}

Although Britain was the birthplace of the railways, in recent decades it has lagged behind in their development. Nevertheless, it still holds the world speed records for both steam and diesel traction, but its electrification ratio is not as high as that in many other countries. Even at the beginning of the 20th Century, speeds of over $160 \mathrm{~km} / \mathrm{h}$ were reached by steam trains, then the 1930's saw developments in streamlining which enabled the locomotive Mallard to reach $203 \mathrm{~km} / \mathrm{h}$ on 3 July 1938, a record which stands to this day. The fifties and sixties were periods of contraction of our railways, as competition with the car intensified. Steam traction was phased out rather rapidly: by 1967 it has ceased and many different types of diesel trains were introduced. Some electrification of main routes, notably the route from London to Manchester took place in the sixties which reduced journey time and increased patronage. A bold attempt was made to design and operate a tilting train to cope with the curves on the sinuous routes to Scotland. The so-called Advanced Passenger Train (APT) incorporated many features novel to the railway industry (Fig. 2), through the efforts of aeronautical and other non-railway engineers injected into British Rail's research laboratories in Derby. The complexities were many: the powered tilt system (up to $9^{\circ}$ ) had a lagging response, the novel hydrokinetic brakes had to deal with stopping distances within the existing block signalling system, the construction was in lightweight aluminium and the carriages were articulated. In 1975 a speed of $245.1 \mathrm{~km} / \mathrm{h}$ was achieved on unmodified conventional track, but the project was dogged by difficulties. A sound, but perhaps in hindsight, too advanced concept, the train was finally abandoned in 1987. However, the expertise generated by the project fed into the design of what has arguably been the UK's most successful train ever, the InterCity 125 High Speed Train (HST) (Fig. 3). This train, based on diesel power cars at each end hauling various combinations of conventional coaches, was introduced into service in 1976. The modern appeal of its clean aerodynamic lines bolstered by a publicity campaign. This is the age of the train, rapidly established its popularity in the eyes of the travelling public. In November 1987 it achieved what is still the world speed record for diesel traction when it touched $238 \mathrm{~km} / \mathrm{h}$. Even today, this train forms the backbone of several major intercity routes in the UK, and is regarded by many, the authors included, as still the best train on the UK network.

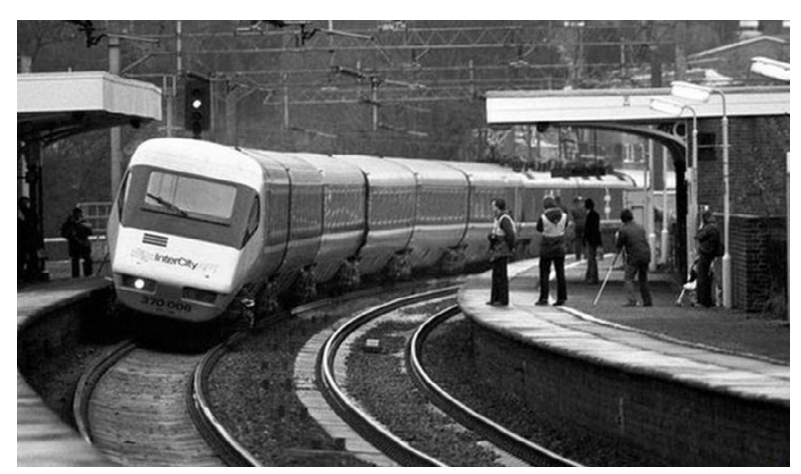

Fig. 2 The Advanced Passenger Train (APT): articulated and tilting; a victim of complexity

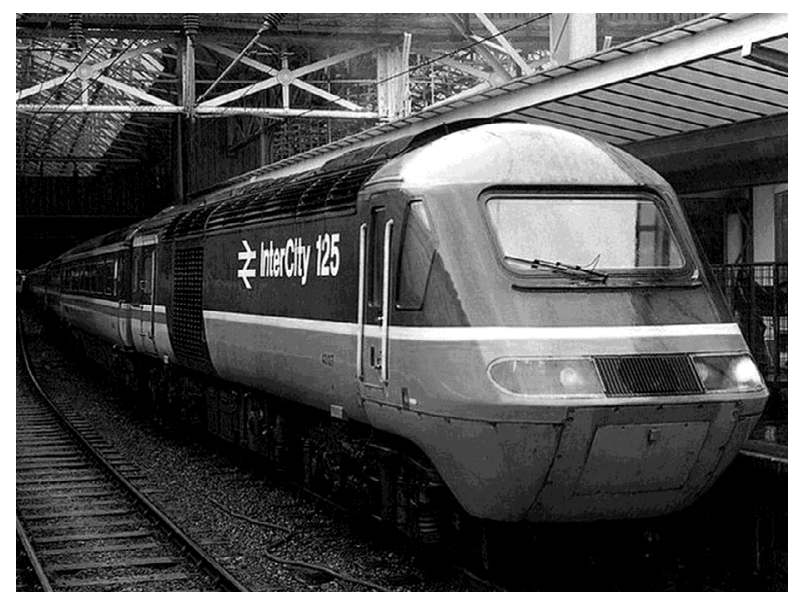

Fig. 3 The 125 High Speed Train (HST): introduced in 1976 and still going strong today

It is the holder of the world's diesel traction speed record of $238 \mathrm{~km} / \mathrm{h}$

A further spin-off from the advanced passenger train project was the InterCity 225 , an electric version of the HST, introduced in 1990. Although designed to travel at $225 \mathrm{~km} / \mathrm{h}$, the speed in service has been limited to $200 \mathrm{~km} / \mathrm{h}$ because of the lack of in-cab signalling. Nevertheless, in a test run it achieved a speed of $261.7 \mathrm{~km} / \mathrm{h}$. The train is still used on the so-called East Coast Main Line to the north from King's Cross in London to Doncaster, York, Newcastle and Edinburgh. 


\section{Channel Tunnel and its link to London}

Twenty years ago, on 6 May 1994, the $50.5 \mathrm{~km}$ long Channel Tunnel opened, linking at last Britain to France and onwards to Western Europe by rail. This project had an incredibly long history: a scheme was first mooted in 1802, followed by several others, which in 1881 resulted in physical exploratory works starting on both sides of the Channel, but which were soon abandoned because of doubts about national security. Finally modern defence technology helped to overcome isolationist views and real work on the project started in 1988. The tunnelling preceded smoothly, the chalk undersea geology between Folkestone and Calais was favourable to tunnelling, but the costs escalated and far exceeded the initial estimates. The scheme of the tunnel is that twin bores connected by a service tunnel and pressure release ducts. The tunnel carries, of course, passenger trains, but also car and freight shuttle wagons onto which vehicles are driven for the passage. Speeds in the tunnel are limited to $160 \mathrm{~km} / \mathrm{h}$. When the tunnel was opened, Paris was connected to Calais by new dedicated high speed line, making speeds of $300 \mathrm{~km} / \mathrm{h}$ possible. On the British side, trains travelled on convention track at a much more sedate speed (apologists said this was to allow passengers to appreciate the wonderful views of Kent, the so-called Garden of England), to a temporary terminal at London Waterloo station.

Some ten years after the opening of the tunnel, a dedicated high speed link, the $111 \mathrm{~km}$ Channel Tunnel Rail Link (CTRL) was opened: Briton's first dedicated High Speed line allowing $300 \mathrm{~km} / \mathrm{h}$ running from the tunnel to a newly refurbished St Pancras station (Fig. 4). So-called High Speed 1 (HS1) because of its UK pioneering role, subsequent developments take up the name HS2, and so on. London to Paris is now $2.25 \mathrm{~h}$ by rail and air traffic has shrunk to very low volumes, rail having an $85 \%$ market share.

Two valuable lessons can be learned from the Channel Tunnel experience. The first is that the hybrid Eurostar train designed to deal with running on dedicated line in France and conventional line in the UK, was not one thing or the other: it had to cope with three different current collections systems, including the antiquated low voltage DC third rail system south and east of London in the UK, and it had three dif- ferent signalling system and had to operate within the restricted loading gauge of the UK network. All these factors added both to complexity and expense, and reduced reliability. Secondly issues relating to safety have arisen. Major fires occurred in the Tunnel in 1996 and 2008, both originating from Heavy Goods Vehicles (HGV) on shuttle wagons. There have been several breakdowns resulting in severe disruptions to services. The service tunnel has proved its worth, but the vulnerability of long tunnel systems and the lack of alternative paths should always be uppermost in operators' minds. Finally on HS1, a domestic service is run, by Hitachi Javelin trains which run on both the dedicated high speed line and on/off to conventional track (Fig. 5). Several of the issues of dual compatibility have arisen adding to the complexity of the trains.

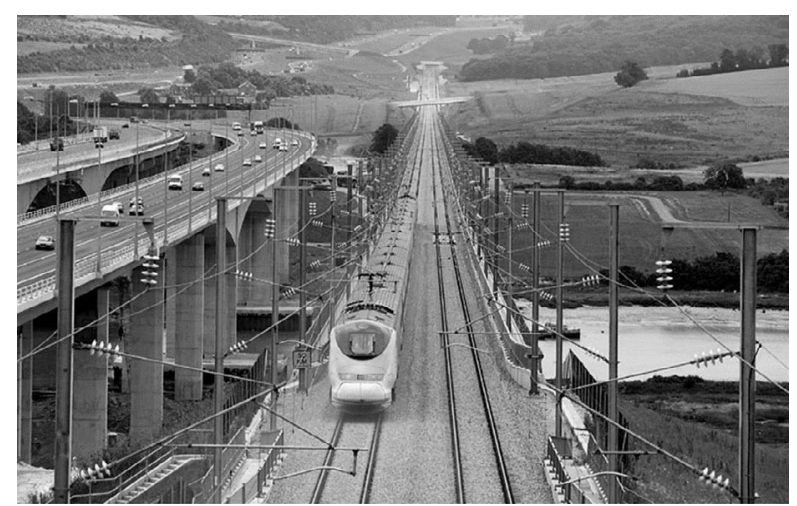

Fig. 4 A Eurostar train on Britain's first dedicated HS1 line linking London and the Channel Tunnel

Note the smaller footprint compared with the parallel motorway

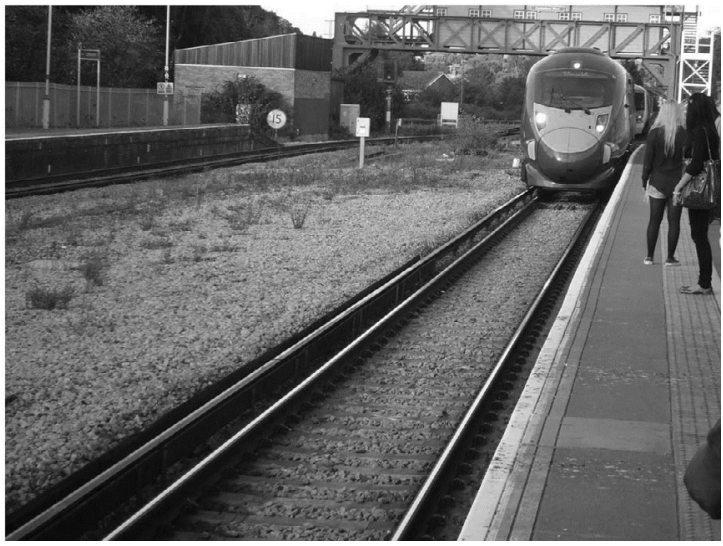

Fig. 5 Domestic services provided by the Hitachi Javelin trains: seen here operating on conventional track with a third rail $750 \mathrm{~V}$ DC current supply 


\section{Development of high speed in Europe}

The significant openings of dedicated high speed line symbolized the development of high speed in Europe (Fig. 6). Seventeen years after the opening of the Shinkansen in Japan, France inaugurated the first true high speed service in Europe when the dedicated line from Paris to Lyon opened in 1981. In many technical aspects the Train à Grande Vitesse (TGV) differed from the Shinkansen. The line was built with more severe gradients, but cut straight lines across Frances rather sparsely populated countryside. Power cars at front and rear led to rather higher axle loads, $17 \mathrm{t}$, and public social spaces such as bar areas led to lower passenger densities and, in general, a much higher structural mass per seat. Double decker or duplex carriages have been introduced to improve capacity on some popular routes. The carbon footprint, however, was very low because of the high nuclear generating capacity in France (interestingly, the original intention was for gas turbine power to be used, but the idea was dropped after the 1973 oil crisis and conventional electric power from overhead supply lines substituted). Over the succeeding years, further lines have been added, basically on a radial pattern from Paris, and more destinations were added to the TGV network through on/off running onto convention tracks. The current dedicated network is just over $2000 \mathrm{~km}$. Although the frequencies of departures of the TGV fall way below the intensive service offered by the Shinkansen, the punctuality leaves something to be desired, an issue compounded by the mixed running. It is also worthy of note that a new generation modified and shortened version of the TGV achieved the world speed record of $574.8 \mathrm{~km} / \mathrm{h}$ on 3 April 2007: speeds in service are, of course, considerably lower, $320 \mathrm{~km} / \mathrm{h}$ is the typical maximum. The France efforts earned them considerable recognition in Europe with the result that other countries were persuaded to join the high speed revolution.

Germany was the next to enter the High Speed arena with its Inter City Express (ICE) trains in 1991. But the network is quite different from those of the Shinkansen and the TGV. Germany, the more so after reunification, is a large polycentric country lacking a single city focus like Tokyo or Paris. Much of the running of TGV trains is on conventional track, although upgraded to allow 160 or $230 \mathrm{~km} / \mathrm{h}$ running. Very little is run at $300 \mathrm{~km} / \mathrm{h}$ on dedicated lines. Nevertheless, the ICE has captured the public's imagination and is rightly known as the flagship of the German railways. Several services run into adjacent countries: France, Austria, Switzerland, The Netherlands, Belgium, and Denmark.

Spain was a later but important entrant. The Madrid Seville service opened on dedicated track in 1992. The Alta Velocidad Española (AVE) translates to Spanish High Speed, but the initials are also a pun on the word ave, meaning bird. Uniquely, on the line from Madrid to Seville, the service guarantees arrival within $5 \mathrm{~min}$ of the advertised time, and offers a full refund if the train is late, although only a very small

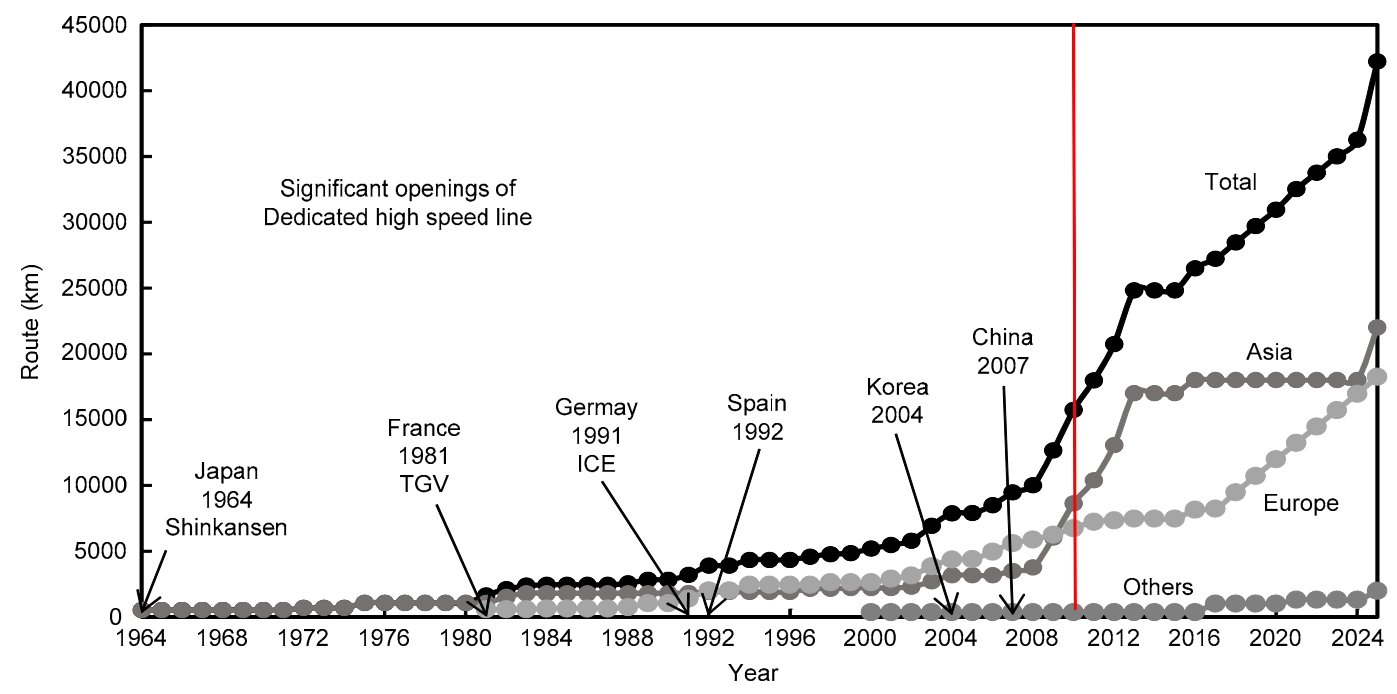

Fig. 6 Development of dedicated High Speed lines in the world 
number $0.16 \%$ are so delayed. Spain now has over $3000 \mathrm{~km}$ of high speed lines: the second in the world only to China. One might also make particular mention of Turkey where in recent years over $1400 \mathrm{~km}$ of track has been cleared for $200 \mathrm{~km} / \mathrm{h}$ operations.

\section{Safety of high speed trains}

Japan has an enviable and remarkable safety record. Not a single fatality due to train accidents since its inauguration and more than 10 billion passengers carried. The Japanese interpretation of this is that, "the system is designed to prevent even the risk of a collision. The key elements of crash avoidance are the use of exclusively dedicated tracks which completely exclude freight and commuter rail being on the same tracks, no at grade crossings of any sort, and an Automatic Train Control (ATC) system, which automatically detects train position and controls the operation of the system." The further claim is that "these elements together maintain safety, advanced energy performance, high speed, large volume, high frequency, and other advantages of operation of the system." Perhaps modesty prevents the claim that this safety record depends too on human factors, particularly the education and continual training of staff and their acceptance as an essential ingredient of the whole system. The major lesson to be drawn here is that high speed trains are indeed a system comprising infrastructure, vehicles, control and people. That infrastructure, vehicles, and operations are best run as a single unit is an obvious conclusion.

Other systems in the world have not maintained an unblemished record, but it is noted that no fatal accidents have occurred on separated high speed track The tragedy at Eschede which killed 101 people on 3 June 1998 involved an ICE train on convention track (Fig. 7). The first author was consulted by Deutsche Bahn in the aftermath: the immediate cause was the fatigue failure of the rim of a resilient wheel. The design had failed to measure the dynamic response of such an unusual construction, and laboratory tests had failed to identify the critical failure region of the inside of the rim. Furthermore, no account was taken of the removal of material from the tread of the rim in order to maintain profile and its effect on reducing the bending stiffness of the rim. The major accident at
Santiago de Compostela in Spain occurred on 24 July 2013, when an Alvia high-speed train, derailed at high speed on a curve about $4 \mathrm{~km}$ outside the station. Of the 222 people aboard, around 140 were injured and 79 died. Investigation showed that the train was travelling at twice the allowed maximum for the curve and was operating outside the ATC system of the dedicated track on a length of conventional track as it approached the station. Similarly, on 23 July 2011, two high-speed trains travelling on the Yongtaiwen railway line collided on a viaduct in the suburbs of Wenzhou, Zhejiang province, China, killing 40 passengers (Fang, 2011). High speed was not a factor in the accident, since neither train was moving faster than $99 \mathrm{~km} / \mathrm{h}$. It has been acknowledged that the accident was caused by a failure of the signalling and control system, but the exact details remain unclear. In the aftermath, maximum speeds were reduced somewhat on the Chinese high speed system, a sensible measure allowing time for the marriage of human factors into the system and allowing for a sensible bedding in period of the new infrastructure. We note once more that none of these accidents have occurred on dedicated, ATC controlled high speed lines.

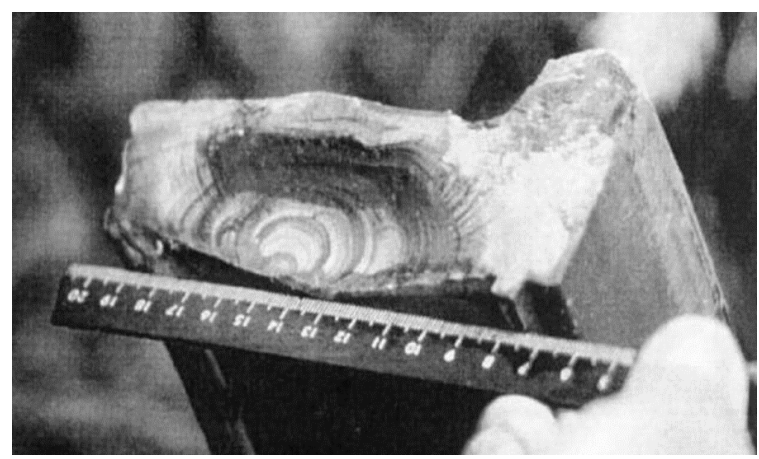

Fig. 7 Clear signs of the development of a fatigue crack in the fractured wheel rim which caused the Eschede disaster of June 1998

Much is made of the comparison of the safety records of different modes of transport. Perhaps too much attention is paid to this kind of data. We choose a transport mode for its appropriateness and availability. For example, a short journey to the local shops is undertaken on foot, car or by bicycle and not by airplane, even though flying has in general an enviable safety record and cycling does not! In comparison with cars, trains are much safer per passenger $\mathrm{km}$ 
travelled. A curious statistic from the UK is that in recent years, more people have been killed on the roads per year than the total number of passenger killed on railways since their inception. The price of safety is eternal vigilance, attention from the humans can and has in many cases been replaced by automated systems, but the standards of maintenance of equipment, vehicles, and infrastructure must be extremely high: this is a substantial part of the ongoing costs of running a high speed railway.

\section{Railway research in the UK}

When the railways of the UK were integrated under British Rail, the national research laboratories were located in Derby and became a world renowned centre for railway research. Particular successes might be mentioned: the dynamics of bogies, signalling systems, and operations control research.

The privatisation and fragmentation of the railways from 1995 lead to a much more stringent financial view of research based on shortermism. The closure of the national laboratories resulted in some parts being sold to private concerns. A few of these survive as consultant partners to the industry, but much of the technical in house expertise and stored knowledge was lost. More recently a more strategic view has prevailed and an attempt has been made to reintroduce some longer term thinking, mainly based around university research groups. More than 40 universities are joined together in a grouping called Railway Research UK (RRUK), carrying out EPSRC (The Engineering and Physical Sciences Research Council) funded projects; however, RRUK ended in this form in about 2010. RRUK survives in what is now known as RRUKA (The Rail Research UK Association), which is a grouping of partner universities and industry with some limited funding provided by RSSB (The Rail Safety \& Standards Board). Major contributions to these efforts are made at the universities of Birmingham, Huddersfield, Newcastle, Nottingham, Sheffield, and Southampton. Again full details can be found on their respective websites. Whilst this research is both useful and commendable it lacks the synergistic effects of a single centre, and the ability to perform large scale experimental work from a long term perspective has been lost.
The authors' own research efforts have been associated with the Future Rail Research Centre at Imperial College London (FRRC) which has been generously supported by Network Rail, the Royal Academy of Engineering and by Hitachi. Some of the major topics which have been studied over the last decade or so are outlined and referenced below.

Several Chinese students have worked in the Centre. Not surprisingly the development of the railway system in China has been of considerable interest (Xue et al., 2002a; 2002b), but these papers predated the rapid development of the high speed railway in China which richly deserves a further study. Connections with Japan and its railways have been strong. Several students from FRCC have spent periods working at universities in Japan and at the Railway Technical Research Centre (RTRI) in Tokyo. The first author has spent periods as a Visiting Professor at Tokyo University, supported by JR (Japan Railway) Central Railway Company, Kyushu University and at the Tokyo Institute of Technology. A paper reviewing the birth of the Japanese Shinkansen (Smith, 2003) proved to be a catalyst for the UK railway when a Minister of Transport was impressed by the story it told. Bringing this up to date, a new paper has reviewed the history of the Shinkansen (Smith, 2014) to mark its 50th anniversary in 2014.

The first author studied fatigue and structural integrity for many years at the beginning of his research career. There are many applications in railways: in fact fatigue came to be studied in the early days of the railways because of broken axles (Smith and Hillmansen, 2004). This theme has been taken up and revisited applying modern developments in fracture mechanics (Hillmansen and Smith, 2004). In the early days of the privatisation of the railways in the UK, issues involving rolling contact fatigue of rails caused a significant accident which led to considerable efforts to rediscover issues originally well understood by British Rail Research. The first author was involved in investigating technical aspects of the accident in question: and some of the advances in understanding were discussed in a review (Zerbst, 2009).

Recent years have seen increasing attention being paid to global warming: therefore the energy and emissions performance of the railways had come under scrutiny (Inderwildi and King, 2013). The 
widely held view is that railways are one of the most energy efficient modes of transport (Smith, 2003a; 2003b), but there are several caveats to this simple view (not the least of which is the load factor of passengers). Issues such as driving style (Read et al., 2011) and alternative energy sources (Read et al., 2009) have been studied.

In principal, the faster we go, the more energy we use. Thus, the topic of energy use of high speed trains raises many questions (Zhou and Smith, 2013). Many aspects have been studied using the FRRC train energy calculator and many sensitivity studies have been computed (Zhou and Smith, 2013; 2014).

Switches and crossing are very costly in terms of maintenance and the dynamics of the passage of a train through a crossing causes many interesting dynamic loads which lead to several types of deterioration mechanisms. A major study has been performed for Network Rail, starting with a statistical analysis of failures on the working railway (Cornish and Smith, 2011), experimental measurements of loads and stresses in crossings in service (Cornish and Smith, 2014) and theoretical considerations of the complex series of contacts between wheel and rail during the traverse of a crossing (Coleman et al., 2012).

More than 20 years ago, the first author was Chairman of a major project undertaken by British Rail Research to develop crashworthiness standards for railway vehicles. The basic mechanism was the absorption of energy by controlled plastic deformation to the ends of rail carriages and a limit on the deceleration experienced by passengers. The project involved verification of computed results by the crushing of full scale vehicle ends and a full scale highly instrumented train collision. The results were incorporated in the UK and European standards for rail vehicle design. It would probably be impossible for the UK rail industry to carry out such a project today. However, detailed research is ongoing although of a computational rather than experimental nature (Xue et al., 2005; 2007).

Several studies of a more general nature have been undertaken, including a study of ways of introducing new technology to the railway industry (Lovell et al., 2011) and ways of increasing innovation into an essentially conservative industry (Lovell and Smith, 2008).
Finally, although railways are considerably safer than many other modes of transport, safety is both costly and requires eternal vigilance. It is therefore a worth topic of study (Santos-Reyes et al., 2005).

\section{Development of high speed in China}

In Asia, Korea opened its Seoul-Busan line 40 years after the opening of the Shinkansen. However, the most remarkable developments in Asia have occurred more recently in China. The development of high speed rail surged in 2010 (Fig. 6), and the main contribution has to be attributed to China. The pace of China's development has been absolutely astonishing. The medium-to-long term railway network development target is to cover China's major economic areas with eight high-speed rail corridors, four running north-south and four going east-west. China now has by far the world's longest network of dedicated high speed lines much of which has been built in the last seven years and more are promised in the next two years, bringing the total length to about $18000 \mathrm{~km}$. Currently, over 1.33 million passengers travel on the Chinese network every day.

Before the introduction of high speed rail, China's overall railway technology and equipment was similar to that of developed countries in 1970s due to historical reasons. China initially conducted independent attempts to develop high speed rail technology domestically, and some notable results include the China Star. However, if to use only their own resources and expertise, China might need a decade or even longer to catch up with developed nations in high speed rail technology. China's early high speed trains were initially imported or built under technology transfer agreements with foreign train-makers including Siemens, Bombardier, and Kawasaki Heavy Industries. In 2004, the Chinese State Council and the Ministry of Railways decided to introduce foreign advanced technology, in order to bring the joint design and production, and finally to build Chinese brand.

Chinese engineers then re-designed train systems and built indigenous trains based on selfdeveloped key techniques. To unite the academic and industrial research interests and resources, the Chinese Ministry of Science and Technology and the 
Ministry of Railways set up a "China's High Speed Train Innovation Joint Action Plan" in 2008. On 30th June, 2011, the World's longest high speed line linking Beijing and Shanghai was completed, with a world record speed of $486.1 \mathrm{~km} / \mathrm{h}$ (Fang, 2011).

The development of high speed rail has risen research interests from many aspects in China. Till now, contributions have been made from: infrastructure (Duan et al., 2011; Yang and Shi, 2014), traction system (Chang, 2014), operation strategy (Lu et al., 2011), aerodynamics (Li et al., 2011; Yu et al., 2013; Cui et al., 2014), etc. On a recent trip from Hangzhou to Beijing, the first author was astonished by the excellent ride quality of Chinese trains operating at speeds over $300 \mathrm{~km} / \mathrm{h}$, and by the passenger service and comfort matching anything offered in other regions of the world. One can only stand back in astonishment and applaud China's remarkable achievement.

However, from the author's personal perspective, some issues may still need a bit further consideration: The design life of slab track is usually around 60 years; however, no slab track system in the world currently lives long enough to examine its end-of-life stage. Whether the system is able to withstand the long period depends hugely on the quality of concrete. Periodical renewal of components is required to maintain the riding quality. After a period of service, the strength of the infrastructure decreases and crack may initiate in some components, thus the rail infrastructure is more vulnerable to sudden external impacts, like natural disasters. It is likely for the infrastructure to fail before the predicted end of its service life. For safety reasons, non-destructive testing method could be needed to examine the cracks which might be embedded in the core of a slab.

\section{Future high speed rail in the UK}

Plans are now being made to extend the high speed rail system of the UK: a project known as High Speed Two (HS2). The principal drivers are that the existing conventional network is overcrowded and has seen a huge increase in patronage in recent years (an increase in passenger $\mathrm{km}$ of $100 \%$, doubling from 750 million in 1995 to 1500 million now, leading to levels of traffic as great as any since about 1910 but on a network of approximately half the size), the population of England is growing rapidly, what was 52 million in 2008 will become 60 million in 2033 and 70 million by 2050 , and there is a pressing need to develop the industrial towns of the north by better interconnections between themselves and with London. Although the proposed network will eventually cover most of the country, the initial plan is for a Y-shaped network, from London to Birmingham then onwards to Manchester and Leeds. There is considerable opposition from people who live near the proposed line: as there was for HS1 to the Channel Tunnel, but the consensus then was that when the line was built, the results were by no means as discomforting as the opponents originally feared. There is also opposition of the grounds of costs: could more be achieved by improving the existing network, or spending the money on other "good" things: schools, hospitals, social services, etc.? Currently there is a consensus amongst the major political parties that the project should go ahead and appropriate Bill is being steered through Parliament: a process which may take two or more years. The timetable may appear leisurely to many people: the plan is to start construction in 2016/2017 and to open the first sections by 2026 . This is a constraint of a democratic parliamentary system but simultaneously is a frustration to the achievement of a long overdue addition to the transport infrastructure of the country. It is unlikely that any procurement of rolling stock will take place until around 2020: by then many innovations and improvements will have been made, but we are assured that all offers both domestic and international will receive fair and open consideration.

\section{Concluding remarks}

As the 50th anniversary of the opening of the world's first dedicated High Speed railway approaches, we can reflect on how the Japanese Shinkansen has become a catalyst for the development and rebirth of railways in many other countries in the world. In Europe, France and Germany led the way, but the most astonishing aspect has been the more recent development of an extensive High Speed system in China, surpassing by far on scale all previous developments and still growing rapidly. 
It has become a priority to increase the efficiency and convenience of transport without adding to carbon generation. The High Speed train system offers considerable advantages in this area, all the more so if renewable sources of electricity can be employed. Although not discussed in this paper, the development of new High Speed transport hub stations presents an opportunity to move away from existing congested city centres and so improve the quality of live in urban areas which have become choked with the ubiquitous automobile.

\section{Brief bibliography}

The followings are particularly useful books on the British, Japanese and German railways respectively:

Simmons, J., Biddle, G., 1997. The Oxford Companion to British Railway History. Oxford University Press, Oxford, UK.

Hood, C.P., 2006. Shinkansen: From Bullet Train to Symbol of Modern Japan. Routledge, London, UK.

Herrmann, H., 1996. ICE High-tech on Rails (3rd Ed.). Hestra-Verlag, Darmstadt, Germany.

A comprehensive account of the origins, development, building and operation of the Chinese High Speed rail system is awaited. Considerable material can be accessed on the internet, with the usual health warnings for accuracy.

The annual report of various railway undertakings are available online and contain much useful information. The Japan Railway and Transport Review (JRTR) is an Englishlanguage transport magazine published quarterly since March 1994 by East Japan Railway Culture Foundation. It is available online at http://www.jrtr.net/ and is an invaluable source.

\section{References}

Chang, Y., 2014. Optimal harmonic filters design of the Taiwan high speed rail traction system of distributer generation system with specially connected transformers. International Journal of Electrical Power \& Energy Systems, 62: 80-89. [doi:10.1016/j.ijepes.2014.02.014]

Coleman, I., Kassa, E., Smith, R., 2012. Wheel-rail contact modelling within switches and crossings. International Journal of Railway Technology, 1(2):45-66. [doi:10.4203/ ijrt.1.2.3]

Cornish, A., Smith, R., 2011. Investigation of failure statistics for switches and crossings in the UK. Proceedings Railway Engineering Conference, University of Westminster, London.

Cornish, A., Smith, R., 2014. Field experimental studies of railway switches and crossings. International Journal of Railway, in press.

Cui, T., Zhang, W., Sun, B., 2014. Investigation of train safety domain in cross wind in respect of attitude change. Journal of Wind Engineering and Industrial Aerodynamics, 130:75-87. [doi:10.1016/j.jweia.2014.04.006]
Duan, Y.F., Zhang, R., Zhao, Y., et al., 2011. Smart elastomagneto-electric (EME) sensors for stress monitoring of steel structures in railway infrastructures. Journal of Zhejiang University-SCIENCE A (Applied Physics \& Engineering), 12(12):895-901. [doi:10.1631/jzus.A11GT007]

Fang, Y., 2011. On China's high-speed railway technology. Journal of Zhejiang University-SCIENCE A (Applied Physics \& Engineering), 12(12):883-885. [doi:10.1631/ jzus.A11GT000]

Hillmansen, S., Smith, R.A., 2004. The management of fatigue crack growth in railway axles. Proceedings of the Institution of Mechanical Engineers, Part F: Journal of Rail and Rapid Transit, 218(4):327-336. [doi:10.1243/09544090 43125879]

Li, X., Deng, J., Chen, D., et al., 2011. Unsteady simulation for a high-speed train entering a tunnel. Journal of Zhejiang University-SCIENCE A (Applied Physics \& Engineering), 12(12):957-963. [doi:10.1631/jzus.A11GT008]

Lovell, K., Smith, R.A., 2008. All Shook Up: an Exploratory Study of Innovation Routes for UK Railway Rolling Stock. Duysters, G.K.K. (Ed.), Wuhan University Technology Press, Wuhan, China.

Lovell, K., Bouch, C., Smith, R.A., 2011. Introducing new technology to the railway industry: system-wide incentives and impacts. Proceedings of the Institution of Mechanical Engineers, Part F: Journal of Rail and Rapid Transit, 225(2):192-201. [doi:10.1177/09544097JRRT383]

Lu, Q., Wang, B., Huang, X., et al., 2011. Simulation software for $\mathrm{CRH} 2$ and $\mathrm{CRH} 3$ traction driver systems based on SIMULINK and VC. Journal of Zhejiang UniversitySCIENCE A (Applied Physics \& Engineering), 12(12): 945-949. [doi:10.1631/jzus.A11GT006]

Read, M.G., Smith, R.A., Pullen, K.R., 2009. Are flywheels right for rail? International Journal of Railway, 2(4): 139-146.

Read, M.G., Griffiths, C., Smith, R.A., 2011. The effect of driving strategy on hybrid regional diesel trains. Proceedings of the Institution of Mechanical Engineers, Part F: Journal of Rail and Rapid Transit, 225(2):236-244. [doi:10.1177/09544097JRRT374]

Santos-Reyes, J., Beard, A., Smith, R.A., 2005. A systemic analysis of railway accidents. Proceedings of the Institution of Mechanical Engineers, Part F: Journal of Rail and Rapid Transit, 219(2):47-65. [doi:10.1243/095440905 $\mathrm{X} 8745]$

Smith, R.A., 2003a. The Japanese Shinkansen: catalyst for the renaissance of rail. The Journal of Transport History, 24(2): 222-237. [doi:10.7227/TJTH.24.2.6]

Smith, R.A., 2003b. Railways: how they may contribute to a sustainable future. Proceedings of the Institution of $\mathrm{Me}$ chanical Engineers, Part F: Journal of Rail and Rapid Transit, 217(4):243-248. [doi:10.1243/0954409033 22712847]

Smith, R.A., 2013. Energy for Railways. In: Inderwildi, O., King, D. (Eds.), Energy, Transport, \& the Environment., Elsevier, p.561-576. 
Smith, R.A, 2014. The Shinkansen-World leading high-speed railway system. Japan Railway \& Transport Review, 64: 38-49.

Smith, R.A., Hillmansen, S., 2004. A brief historical overview of the fatigue of railway axles. Proceedings of the Institution of Mechanical Engineers, Part F: Journal of Rail and Rapid Transit, 218(4):267-277. [doi:10.1243/09544090 43125932]

Xue, X., Schmid, F., Smith, R.A., 2002a. An introduction to China's rail transport part 1: History, present and future of China's railways. Proceedings of the Institution of $\mathrm{Me}$ chanical Engineers, Part F: Journal of Rail and Rapid Transit, 216(3):153-163. [doi:10.1243/095440902760 213585]

Xue, X., Schmid, F., Smith, R.A., 2002b. An introduction to China's rail transport part 2: urban rail transit systems, highway transport and the reform of China's railways. Proceedings of the Institution of Mechanical Engineers, Part F: Journal of Rail and Rapid Transit, 216(3):165-174. [doi:10.1243/095440902760213594]

Xue, X., Smith, R.A., Schmid, F., 2005. Analysis of crush behaviours of a rail cab car and structural modifications for improved crashworthiness. International Journal of Crashworthiness, 10(2):125-136. [doi:10.1533/ijcr.2005. 0332]
Xue, X., Schmid, F., Smith, R.A., 2007. Analysis of the structural characteristics of an intermediate rail vehicle and their effect on vehicle crash performance. Proceedings of the Institution of Mechanical Engineers, Part F: Journal of Rail and Rapid Transit, 221(3):339-352. [doi:10.1243/ 09544097JRRT77]

Yang, X., Shi, G., 2014. The effect of slab track on wheel/rail rolling noise in high speed railway. Intelligent Automation \& Soft Computing, 20(4):575-585. [doi:10.1080/10798587. 2014.934597]

Yu, M., Zhang, J., Zhang, W., 2013. Multi-objective optimization design method of the high-speed train head. Journal of Zhejiang University-SCIENCE A (Applied Physics \& Engineering), 14(9):631-641. [doi:10.1631/jzus.A1300109]

Zerbst, U., Lunden, R., Edel, K., et al., 2009. Introduction to the damage tolerance behaviour of railway rails - a review. Engineering Fracture Mechanics, 76(17):2563-2601. [doi:10. 1016/j.engfracmech.2009.09.003]

Zhou, J., Smith, R.A., 2013. Energy use of high speed trains: Case studies on the effect of route geometry. 12th International Conference on Railway Engineering, London, UK.

Zhou, J., Smith, R.A., 2014. High speed trains: the influence of route geometry and train configuration on energy consumption. International Journal of Railway, in press.

\section{中文鳞要:}

本文题目: 中国, 英国与欧洲的客运铁路的近期发展背景

Background of recent developments of passenger railways in China, the UK and other European countries

本文概要: 本文基于作者于 2014 年 5 月在中国参观铁路建设成就时的一篇报告而写成。内容涵盖铁路发 展历史简介，英国和中国铁路的对比，英国过去数十年间铁路提速情况的说明以及现有高速 铁路的介绍。此外, 本文还详细讨论了欧洲高铁的发展情况和铁路系统安全的分析比较, 并 对中国高铁的发展及英国高铁建设计划进行了说明。得出高速铁路系统在提高能量利用效率、 增加旅客舒适度、控制碳排放量等方面有显著优势。

关键词组: 铁路; 高速; 安全; 历史; 列车; 基础设施; 系统 